\title{
Cabra marcado para morrer: um filme entre história e memória
}

Roberto Abdala Junior*

Resumo: O texto é resultado de uma pesquisa sobre o filme Cabra marcado para morrer, do cineasta brasileiro Eduardo Coutinho (1984). O trabalho explora algumas possibilidades de apreender o impacto da obra na época em que ela vem a público. Trata-se de uma pesquisa de caráter historiográfico, tomando a Didática da História (RÜSEN) como paradigma teórico, recorrendo às teses de Vygotsky, Bakhtin e Williams de forma articulada para demonstrar como muitos dos procedimentos empregados pelo cineasta são análogos aos empregados por historiadores. Assim, investigamos as possibilidades de apreendermos as relações que o filme estabeleceu com a cultura história dos anos 1980 e como a narrativa pode ser considerada uma obra "entre memória e História", aproximando-se de uma escrita audiovisual da história.

Palavras chaves: Didática da História. História e narrativas audiovisuais. Ditadura.

Penso que a escrita do historiador está mais próxima da montagem de um filme do que, por exemplo, da narrativa de um romancista.

Jacques Le Goff ${ }^{1}$

*Doutor em História pela Universidade Federal de Minas Gerais - UFMG.
Professor da Universidade Federal de Goiás - UFG. E-mail: abdalajr@gmail.com Anos 90, Porto Alegre, v. 24, n. 45, p. 267-292, jul. 2017 


\section{Introdução}

As relações entre história e cinema sempre encantaram e desafiaram historiadores e cineastas. O texto a seguir aborda o tema de forma ampliada e atualizada, como história/História e narrativas audiovisuais. Não há pretensão de realizar um estudo sobre esse universo temático, mas sim de explorar um recorte teórico-metodológico que apresenta questões sobre essas intrincadas relações para as quais as respostas não são, unicamente, teóricas.

O objeto de estudo que vamos explorar, com o fito de demonstrar algumas possibilidades de responder às questões sobre o tema, é o documentário Cabra marcado para morrer (COUTINHO, 1984). A narrativa audiovisual que é objeto da análise visa a responder as seguintes questões: é possível a representação audiovisual do passado 2 ? Como a linguagem audiovisual emprega elementos da realidade ao representá-la?

Decorre das questões anteriores a interrogação primeira deste estudo: como uma narrativa audiovisual sobre experiências do passado de uma sociedade aproxima-se da narrativa historiográfica? Apesar de contrariar as convenções historiográficas mais recentes, o estudo será precedido de uma argumentação teórica sumária. $\mathrm{O}$ procedimento é necessário devido à complexidade do problema. A intenção final é apresentar, explorar, demonstrar analogias entre as duas categorias de narrativas e colocar em debate um quadro conceitual que nos parece muito pertinente a esse tipo de investigação.

\section{Considerações teóricas preliminares}

\section{Proposições teóricas em diálogo}

Os autores que servem como referência ao "diálogo"” teórico que orienta nossa análise são amplamente conhecidos: L. S. Vygotsky, M. M. Bakhtin e R. Williams. Os objetos aos quais dedicaram suas pesquisas e reflexões são muito distintos - a mente humana, a linguagem e as manifestações culturais, incluindo as midiáticas, 
respectivamente e em sentido lato. Seus argumentos oferecem uma possibilidade rara de articulação entre esses campos de conhecimento, como o próprio Williams defendeu em $1971 .^{4}$

A articulação entre áreas de conhecimento distintas pode ser defendida, nesse caso, porque, embora cada autor tenha se dedicado a um campo específico de pesquisa - Vygotsky, à psicologia sociocultural; Bakhtin, à filosofia da linguagem e Williams, à sociologia da cultura - todos foram obrigados a considerar o papel da linguagem para que seus estudos avançassem. Noutros termos, o que permitiu a convergência de muitos dos argumentos, o deslocamento para um viés comum de abordagem e perspectivas epistemológicas, além da aproximação de algumas noções para objetos e campos distintos foi a resposta ao problema da linguagem que cada área apresentava.

Algumas das reflexões e argumentos disciplinares são considerados complementares. Vamos explorar aqueles que podem ser tomados em comum, mas tendo em vista que foram aprofundados mais por um dos autores e menos pelos demais. A intenção é aplicar as proposições de cada autor para esclarecer os processos que envolvem a linguagem nos diversos campos, apontando como ajudam a investigar as complexas relações entre história/História e narrativas audiovisuais.

Em resumo e em sentido amplo, podemos afirmar que os autores concordam que as obras de linguagem são estruturantes da mente humana. Tais obras são operadas em processos de interações sociais necessários para que os seres humanos sejam capazes de lidar com o meio, material e/ou simbólico no qual estão imersos, com o fito de sobreviverem. ${ }^{5} \mathrm{Visto}$ dessa maneira, a comunicação converte-se em elemento fundamental desses processos que são, em essência, antropológicos. ${ }^{6}$

As obras humanas e seus significados são considerados, analiticamente, como respostas às situações reais da vida prática. Decorre dessa premissa que os problemas que as experiências do cotidiano apresentam são enfrentados por uma criatividade humana intrínseca e operatória, segundo a qual se forjam novas "ferramentas" - materiais e simbólicas - em situações histórica e culturalmente dadas, quando há "carências de interpretação" - considerando aspectos históricos (RÜSEN, 2001) - e/ou empobrecimento da "descrição", no sentido de 
ela deixar de responder às demandas socioculturais - pensando nas artes (WILLIAMS, 2003). ${ }^{7}$

O caráter histórico de todas as experiências e manifestações humanas é outro aspecto seminal nas respectivas reflexões dos autores. São, portanto, as características “empiricistas” das reflexões e pesquisas dos autores, a distinção objetiva de seus respectivos objetos e campos de pesquisas, bem como o problema da linguagem nos processos de interação social que configuraram um ambiente favorável para pensar a possibilidade de interdisciplinaridade. A História, especialmente a Didática da História, é um campo a acolher algumas das proposições dos autores, pois a forma de partilhar o conhecimento da história exige o emprego da linguagem, aliás, pensando mais contemporaneamente, das linguagens. (RÜSEN, 2010).

\section{Cultura histórica e memórias}

O termo Cultura Histórica foi proposto por Rüsen (2001, 2010) para se referir a toda produção de uma dada cultura que realiza alguma interpretação das experiências coletivas no tempo. Nesse sentido, as memórias sociais, os discursos históricos oferecidos pela escola, por outros agentes sociais, pela historiografia, mas também pelas artes, pelo cinema, pelo teatro, pelas festas, rituais, etc. entram na composição dessa "cultura histórica". A noção se refere, portanto, ao conjunto de "discursos" que circulam na cultura sobre o passado. A noção de "cultura histórica" é análoga ao "repertório cultural" bakhtiniano (BAKHTIN, 1997), considerando os discursos sobre um aspecto e/ou fenômeno do passado que é partilhado por parte da sociedade em questão e numa determinada época.

\section{O enunciado como problema: pensando historicamente}

Bakhtin, partindo da premissa partilhada com Vygotsky de que a principal e antropológica função da linguagem é a comunicação, argumenta que mais importante para apreender os significados, não são os discursos considerados isoladamente, mas o papel que desempenham para os envolvidos nas interações sociais. Decorre 
dessas considerações que as pesquisas sobre a linguagem devem ter por foco o "enunciado" dos discursos. (BAKHTIN, 1997)

Bakhtin propõe o necessário deslocamento da análise dos significados dos discursos para o contexto sociocultural e histórico no qual ocorre a enunciação, insistindo que somente assim é possível apreendê-los (BAKHTIN, 1992; 1997). Sob esse viés analítico, os significados se enraízam nas práticas sociais nas quais nasceram os discursos e ganham autonomia, no momento do uso contextualizado que os indivíduos (e/ou agentes sociais) fazem do repertório cultural disponível.

\section{Linguagem: fundamentos teóricos e metodológicos}

Segundo Bakhtin, os discursos apresentam um princípio que é intrínseco à linguagem e que rege seu emprego na vida comum: o "dialogismo". Os significados dos discursos são, portanto, engendrados em processos interacionais "dialógicos" que ocorrem em diversas dimensões: entre indivíduos e/ou os agentes sociais, mas também entre eles e as obras/discursos, e/ou com o "repertório cultural", bem como com o contexto não verbal da enunciação. Importa observar que não há hierarquização ou exclusão entre os elementos em "diálogo". (BAKHTIN, 1997).

O dialogismo bakhtiniano é, pois, o elemento metodológico chave para a análise dos discursos e seus significados. Ele permite, de um lado, apreender aspectos dos processos comunicativos que forjam a mente humana (VYGOTSKY, 1994; WERTSCH, 1993) - incluindo seus aspectos ligados às representações do passado (WERTSCH, 1993, 2002). O dialogismo torna possível identificar os significados dos repertórios aos quais é necessário recorrer nas práticas cotidianas. Os discursos que constroem cognitivamente a realidade são mantidos como foco analítico, mas também o são as práticas empíricas, socioculturais e historicamente situadas, no interior das quais eles foram empregados. (VIGOTSKI, 2010, p. 395-486; BAKHTIN, 1992, p. 261-335).

Há a outra dimensão dos diálogos: o impacto da enunciação sobre o(s) interlocutor(es) - o público. As teses bakhtinianas nos 
oferecem, novamente, uma possibilidade de apreender algumas dessas dimensões dialógicas, ao explorarem outra característica precípua dos discursos: a "reação responsiva". O argumento é que, assim como a réplica do diálogo, uma obra/discurso visa à resposta do outro (dos outros), uma compreensão responsiva ativa. Nesse sentido, as teses de Bakhtin propõem que, para alcançar essa "compreensão responsiva" do público ao qual se destina, a obra adota todas as espécies de formas: "busca exercer uma influência didática sobre o leitor, convencê-lo, suscitar sua apreciação crítica, influir sobre êmulos e continuadores" etc. (BAKHTIN, 1992, p. 197).

\section{A narrativa histórica}

Um elemento figura como central e estratégico para a análise, no quadro conceitual com o qual trabalhamos: o papel da narrativa nesses processos, que é concebido em conformidade com as teses de Rüsen. A premissa de que a narrativa consiste de uma realização antropológica que funda uma temporalidade humana compartilhada, entre as duas outras dimensões - cósmica e subjetiva - propostas por Ricoeur é preservada e ampliada em Rüsen. As experiências humanas no tempo ganham articulação em discursos de tipo narrativo, propícios ao compartilhamento de histórias nas interações sociais. Noutros termos, os seres humanos fazem uso dos repertórios culturais com a finalidade de articularem discursos-narrativas que têm por objetivo apreenderem e partilharem a experiência do tempo.

As reflexões desses autores nos permitem considerar também que as obras cinematográficas guardam, pelo menos, dois elementos essenciais das narrativas históricas: primeiro, estão enraizadas na cultura na qual encontram um repertório que atribui significados ao mundo da experiência. Narrativas carregam simbolismo e historicidade, ao recorrerem às convenções e outros elementos dos repertórios culturais nos quais nasceram. Muitas das narrativas cinematográficas também estão empenhadas em superarem as carências de interpretação sobre as experiências do passado apresentadas no presente. $^{8}$

O foco de nossas análises recairá, portanto, nos processos dialógicos de interação da obra com o repertório cultural de época, 
ou - como preferimos, seguindo Rüsen - com a "cultura histórica" brasileira da época, tomando como referência o filme Cabra marcado para morrer (COUTINHO, 1984). O filme é uma fonte histórica privilegiada, pois os processos de interação que entram na construção da obra são reconhecidos e empregados coletivamente pelos realizadores. A obra está, então, em diálogos permanentes com uma diversidade de outros discursos que circulavam na cultura brasileira (sobretudo a cultura política) sobre o passado - em cada época no caso, no início da década de 1960 e em meados dos anos 1980.

Um aspecto de época é importante ser observado: no final da ditadura, como a polarização política havia se aprofundado, também os discursos se tornaram mais facilmente identificáveis com as posturas ideológicas dos agentes sociais, nas disputas que visavam a legitimar sua versão do passado. ${ }^{10} \mathrm{O}$ filme emerge como elemento "indiciário" que configura o campo no qual essas lutas se travavam, embora elas não se restringissem aos elementos aqui analisados.

\section{O contexto histórico de produção}

A década de 1980 na América Latina e no Brasil caracterizou-se pela emergência dos movimentos sociais. No caso brasileiro, desde os anos finais da década de 1970, ainda durante a ditadura militar, irromperam os movimentos sociais com uma pujança desconhecida na história nacional. O mais expressivo entre eles foi, sem dúvida, a emergência do "novo sindicalismo". A política passava também pela Igreja Católica, nas Comunidades Eclesiais de Base - CEBs, muito inspiradas pela Teologia da Libertação, além da emergência das lutas pelos direitos das "minorias", como o movimento das mulheres, dos negros, dos homossexuais etc.

O regime ditatorial fazia água por todos os lados, desde meados dos anos 1970: no campo econômico, os empréstimos internacionais que haviam assegurado o apoio de segmentos da classe média escassearam após a crise do petróleo de 1973, acompanhada pelo avanço inflacionário. No campo social, a classe média começa a se ressentir do apoio dispensado à ditadura, sobretudo por causa do avanço da censura a partir de 1968 (com a decretação do AI-5),

Anos 90, Porto Alegre, v. 24, n. 45, p. 267-292, jul. 2017 
a suspensão dos direitos individuais e a escalada da violência. Os "presos políticos" que abarrotavam as masmorras dos órgãos de repressão e tortura compunham-se, especialmente, de filhos da classe média (RIDENTI, 2000). No âmbito internacional, os militares perderam apoio dos EUA depois da eleição de Carter (1977/81) (SKIDIMORE, 1988). ${ }^{11}$

$\mathrm{Na}$ caserna, os órgãos de repressão e tortura começavam a ameaçar, além das instituições, também as corporações oficiais, garantindo, inclusive, promoções e cargos públicos aos seus membros. Seus poderes faziam frente às próprias hierarquias militares, muitas vezes se sobrepondo a elas, como ficou evidente no "Atentado do Riocentro" (SKIDIMORE, 1988).

Mais tarde, um dos mais importantes movimentos sociais brasileiros da segunda metade do século XX - Diretas Já! - despontou nas cidades, mobilizando milhões de brasileiros ao longo do ano de 1984. Nesse ambiente complexo, configurado por uma efervescente ação política e de crise geral da ditadura civil-militar é que o filme de Eduardo Coutinho vem a público.

\section{Argumento e enredo}

A obra pode ser considerada um meta-documentário, cujo tema é a luta de trabalhadores rurais brasileiros por direitos, bem como o impacto da ditadura militar sobre essa saga (e em alguns de seus líderes de forma emblemática), tendo o período da ditadura militar como recorte temporal. $\mathrm{Na}$ verdade, essa seria uma "descrição" do filme nos anos 1980, quando ele foi, enfim, finalizado.

A história do filme começa em 1962, ano em que João Pedro Teixeira, um líder das Ligas Camponesas - entidade civil que cumpria um papel de sindicato no Brasil da época - é assassinado. Um comício que reuniu cinco mil pessoas foi organizado em protesto ao assassinato do "líder camponês" - termo empregado no filme que remete às concepções da esquerda brasileira na época. $\mathrm{O}$ fato ocorrido num lugarejo de nome Sapélevou Coutinho que trabalhava "há uns cinquenta quilômetros", na capital da Paraíba, a ter a ideia de realizar um filme sobre a vida daquele herói popular. 
O diretor soube do comício quando realizava filmagens como membro da UNE-Volante - uma unidade móvel da União Nacional dos Estudantes, a UNE - que percorria o Brasil para discutir propostas para a reforma universitária. Merece atenção o tipo de mobilização que a UNE realizava então, sobretudo se levarmos em conta que o país somente conquistaria uma rede de telecomunicação nacional em 1970 e sob a ditadura militar.

A cultura histórica brasileira dos anos 1960 não deixa dúvida quanto à intenção da UNE de ampliar diálogos com o "povo", trazendo o debate político e temas de esquerda para seu cotidiano, com o fim de "conscientizá-lo". ${ }^{12}$ Entre as estratégias empregadas estaria o uso do cinema como "agitador das massas", aspecto que Coutinho não explicita, mas que fica evidente no momento em que os vestígios do filme de 1964 é exibido para a comunidade do "Engenho Galiéia", nos anos 1980. Não podemos deixar de observar que a própria experiência de exibir o filme de 1964, realizada nos anos 1980 e registrada pelas câmeras, consiste de um exercício fundamentalmente dialógico, como aqui o concebemos.

A intenção do cineasta de fazer lembrar ao público aquele debate também pode ser depreendida pela menção que o narrador (voz over do poeta Ferreira Gullar) faz sobre a fundação de outros Centros de Cultura Popular-CPC-da UNE. Os CPC's que a entidade estudantil pretendia criar pelo país a fora, reuniam essas duas dimensões: cultural e política. No interior dessas instituições o debate a respeito do papel do intelectual e a necessidade de se conscientizar politicamente o "povo" era acirrado. ${ }^{13}$

As filmagens começaram dois anos depois, nos moldes do docudrama - documentário que dramatiza acontecimentos reais, recorrendo a atores amadores que vivem em condições semelhantes - um traço de historicidade das convenções cinematográficas de época. Foram convidados para atuar alguns moradores da primeira Liga fundada em Pernambuco - no "Engenho Galiléia" - e a família do líder "camponês". O cineasta e sua equipe foram surpreendidos com o Golpe militar de 31 de março de 1964 que impôs ao Brasil uma ditadura, em moldes fascistas - respeitando anacronias, mas destacando um aspecto sempre negado pelos militares - por vinte e um anos.

Anos 90, Porto Alegre, v. 24, n. 45, p. 267-292, jul. 2017 
Os membros da equipe foram perseguidos e foi confiscado tudo o que se referia à filmagem. Mas, como quase metade dos negativos havia sido enviada ao Rio de Janeiro para serem revelados, as cópias puderam ser recuperadas mais tarde e o filme foi retomado dezessete anos depois. Assim, em 1984 Cabra marcado para morrer tem sua primeira exibição pública em São Paulo.

O novo filme não retoma o argumento de 1964. Rompe com o primeiro projeto, abandona as convenções do cinema documentário dos anos 1960 e vai em busca da trajetória de vida dos atores do primeiro filme, inclusive dos filhos e da viúva de João Pedro Teixeira que se transformam em personagens da história/filme. Opera-se então a inserção dos personagens da narrativa nos processos históricos dos quais suas vidas fizeram parte nos últimos dezessete anos contemplando, exatamente, os anos de ditadura.

O cineasta faz um exercício análogo ao de um historiador: oferece ao seu público uma narrativa na qual a história ganha "nova" interpretação para suas experiências do período. A condição social que os personagens representam no filme também ganha dimensão histórica, no sentido que propõe Rüsen, pois eles retomam suas trajetórias individuais, reconhecendo-as como um elemento no interior da história do Brasil, que tem caráter mais amplo, social e que foi/é compartilhada por todos. Os grifos no termo "todos" têm a finalidade de destacar que, no momento da exibição do filme, os brasileiros que fizessem parte do público estariam, obrigatoriamente, partilhando da história em alguma medida (RÜSEN, 2007b).

Muitos outros elementos da cultura histórica de época e/ou do repertório de um conhecimento histórico a respeito da ditadura serão, sistematicamente, interpelados pela obra de Coutinho. O cineasta não poupa ninguém - nem mesmo o público a quem ele endereça sua obra/discurso. O filme, em certa medida e com uma justificativa razoavelmente legítima - como veremos a seguir-exige que o público detenha essa "cultura histórica" sobre a ditadura, independente de ele ser fruto da experiência histórica ou de um esforço para conhecer o passado (escolar, literária, política etc.).

A narrativa cinematográfica é aberta com uma cena paradoxal: observamos imagens recentes (1984/coloridas) do horizonte de uma paisagem rural que emoldura uma moradia simples, em frente dela 
vemos pessoas circulando em torno de uma mesa sobre a qual há um projetor de filmes. A seguir são mostradas imagens (em preto \& branco) de 1962, apresentando uma "passarela" de uma construção em palafitas - um tipo de moradia construída sobre as margens de rios e em condições miseráveis - e crianças trabalhando em regiões ribeirinhas, tendo a música Canção do subdesenvolvido (Carlos Lyra, 1962) ao fundo.

Na letra há referências irônicas à condição do país ("subdesenvolvido") e aos discursos "imperialistas" que circulavam na cultura de então. Segundo a voz over de Gullar que divide a narração com o próprio diretor, "as imagens da miséria se contrastavam com a do imperialismo". Vemos na tela cenas de uma feira - evento muito presente no nordeste - onde circula gente do povo e, ao fundo, logomarcas da Texaco e da Esso (COUTINHO, 1984, 1'36”). Assim, tem início a história do próprio filme que nos é narrada por dois nordestinos: Gullar e Coutinho - ambos, membros dos Centros de Cultura Popular da União Nacional dos Estudantes - CPC's da UNE.

Os realizadores definem, logo na abertura da narrativa, o lugar social do qual "enunciam" seu discurso-obra, estabelecendo claramente suas escolhas ideológicas. O documentário também não deixa margem à ambiguidade, marcando com ênfase sua posição no campo das disputas pela memória. O "sotaque" de ambos "dialoga" com preconceitos velados, alimentados contra os originários desta região do Brasil que formaram a mão de obra, em geral, desqualificada que vai trabalhar por salários míseros, em subempregos nas grandes metrópoles.

$\mathrm{Um}_{\mathrm{m}}$ preconceito ${ }^{14}$ nascido, provavelmente, do fato de formarem o maior contingente de migrantes que aportaram nas "megalópoles" - com suas mega-favelas - fabricadas pelo crescimento desordenado do país. Um fenômeno ampliado, aprofundado e explorado durante o período ditatorial. Uma realidade sempre "apagada" nas narrativas ufanistas oficiais e oficiosas. Narrativas veiculadas, principal, mas não unicamente, pelas mídias; especialmente a televisão, sobretudo a Rede Globo - empresa na qual o cineasta, entre outros intelectuais e artistas de esquerda, trabalhou durante a ditadura. 
A seguir, o cineasta vai exibir seu trabalho de investigação sobre os desdobramentos da ditadura militar sobre os "personagens da vida real" do primeiro filme. Nessa trajetória a obra ganha mais densidade histórica e revela sua importância para a cultura histórica e cinematográfica brasileira, permitindo observar um poder desconhecido do cinema, que talvez tenha sido vislumbrado por Walter Benjamin nos anos 1930.

\section{A história em cena}

Se a narrativa historiográfica estiver mesmo mais próxima da cinematográfica, como afirma o historiador na citação que abre este texto, não é difícil observar esse traço epistemológico no filme de Coutinho. O cabra marcado para morrer é, não somente uma obra-prima do cinema documentário, mas, sobretudo, uma obra na qual os argumentos bakhtinianos sobre os discursos e a construção "dialógica" de seus significados parecem ganhar uma pertinência metodológica dificilmente superável. ${ }^{15}$ Leva a pensar como o cinema permite formular um discurso análogo ao historiográfico, especialmente ao analisarmos as formas de (re)apresentação do passado e os resultados esperados que alimentam esses propósitos.

Uma das estratégias a qual o cineasta recorre, frequentemente, consiste em colocar em tela - nesse caso, na tela "monumental" do cinema - evidências, vestígios do passado em meio a testemunhos orais (emocionantes, é preciso destacar). Ao concebermos a construção de significados nos quadros conceituais bakhtinianos, esse discurso trava diálogos pontuais com o repertório de cultura histórica sobre a ditadura. No momento da exibição/enunciação do filme vai se "revelando" ao/com o público como o regime agiu ao longo de vinte e um anos de ditadura. Mascarando, falseando ou silenciando a realidade brasileira; oprimindo, violentando e/ou corrompendo pessoas, instituições, agentes sociais etc. O recorte que daremos nesta apresentação incidirá, principalmente, nesses momentos da obra: nos seus diálogos com a cultura histórica sobre a ditadura nos anos 1980.

A respeito de uma suposta exigência por parte dos realizadores de o público deter um repertório (ainda que mínimo) sobre 
a história brasileira do período da ditadura e outros aspectos aos quais o filme faz referência ao longo da narrativa, merece destaque o fato de que historiadores tenham passado a denominar a ditadura de "civil-militar" só recentemente, visando a destacar o apoio de segmentos da sociedade civil - efetiva e, muitas vezes, tácita - ao regime. Não parece que agentes sociais mais esclarecidos estivessem dispostos, no passado ou no presente, a reconhecer a situação política na época (REIS FILHO, 2004). Não há dúvida também que essa crítica se atém àqueles que pudessem formular uma interpretação mais complexa da realidade da época.

Sabemos que empresários, proprietários de terras, segmentos da classe média e da Igreja toleraram abusos do regime, apoiaram suas ações de opressão, censura e/ou silenciaram a respeito da ditadura, chegando a se beneficiar da proximidade com o poder. $\mathrm{O}$ interesse em reconhecer e tornar público as prisões arbitrárias, as torturas e assassinatos tardou. No entanto, o mais incisivo e decisivo dos agentes sociais de apoio ao golpe e à ditadura que o seguiu foi, sem dúvida, a mídia, cuja participação pode ser considerada quase unânime, contando com raríssimas e admiráveis exceções, como o jornal Última Hora.

O filme não poderia, portanto, ser conivente com esse aspecto da história, sob o risco de não respeitar o primeiro compromisso de uma investigação dessa natureza: ser fiel ao que se sabe sobre o passado, mantendo um "compromisso com a verdade" - exatamente, por se tratar de um documentário (GUALTHIER, 2011). A obra pode ser tomada, nesse caso, também como um "lugar de [legítima] memória". Um dos elementos que conferem brilhantismo ao Cabra consiste, exatamente, em empregar uma das formas narrativas mais exploradas ao longo da ditadura para legitimar-se - a audiovisual com a finalidade de lhe apresentar um contraponto incontornável que, embora pontual, tornava-se "monumental" no cinema. ${ }^{16}$

$\mathrm{Na}$ maioria das sequências, nas quais a montagem intercala imagens de manchetes de periódicos, os realizadores optaram por "expor" registros de época, de forma que eles estivessem em franca contradição ou que corroborassem com o argumento fílmico em voz off ou over ${ }^{17}$ - dependendo da sequência. O resultado final interpela o público e, em certa medida, o obriga a não receber o discurso 
sonoro de forma ingênua. Os diálogos entre o discurso sonoro e o imagético que apresentam as notícias que circulavam na cultura na época do golpe operam de forma reflexiva, instigando o público a construir por si mesmo a "narração final" que pode ser considerada como resultados dos diálogos entre esses dois discursos e o repertório do público. Vejamos como isso se opera explorando a obra.

Nas primeiras sequências do filme, mesclam-se manchetes de jornais sobre o assassinato do líder "camponês", com imagens dos trabalhadores em direção ao comício de protesto contra o ocorrido. Coutinho informa (voz. over) que foi obrigado a transferir o local das filmagens para o "Engenho Galiléia" porque houve um conflito de terras, no qual estiveram envolvidos "camponeses", polícia militar e empregados de uma usina. Segundo a narração, onze pessoas haviam morrido no confronto e a região foi ocupada pela polícia militar da Paraíba. No entanto, nas imagens apresentadas na tela, vemos somente corpos de "camponeses" (COUTINHO, 1984, 4' 48").

Seguem-se imagens das práticas sociais e condições de vida do "Engenho Galiléia" nos anos 1960, cuja pobreza é evidente e servem também de fundo à narrativa de Coutinho que explica as escolhas que o levaram àquele lugar. As imagens não somente ilustram, mas testemunham as condições que os trabalhadores rurais, "supostamente" enfrentavam no Brasil daquela época. O que está em questão, quando empregamos o termo supostamente, são as convenções das duas formas de narrativa: a historiográfica que poderia recorrer a uma citação para comprovar seu argumento e a cinematográfica, na qual o artifício precisa ser empregado com parcimônia e segundo funções diegéticas muito específicas.

A violência também está presente nestas sequências iniciais. Afinal, "apenas dois dos camponeses que iniciaram as lutas de Galiléia ainda estavam vivos, José Hortêncio da Cruz e João Virgínio da Silva, que não sabe ler nem escrever e é uma espécie de memória da tribo" (COUTINHO, 1984, 8' 55') afirma Gullar, com sua voz (over) grave e marcante, mas sem emoção. A informação é fornecida como um dado sociológico - secamente. A seguir, a voz de um dos sobreviventes invade a cena fílmica. A estratégia narrativa faz com que o público se depare com uma "evidência" empírica: aquele homem do passado reaparece no presente por meio da película. $\mathrm{O}$ 
filme nos faz "testemunhar" - no sentido clássico do termo - que, embora muitos dados pareçam "impessoais" ao serem expressos, eles se referem a homens e mulheres como aqueles que compõem a narrativa e, também, ou sobretudo, o público.

Os nomes dos sobreviventes e a ideia de uma memória "não letrada" já demonstram que as intenções de Coutinho são bem precisas. Ao longo da ditadura, o Estado sempre buscou fundar uma memória coletiva na qual o golpe e o regime teriam se restringido a "combater" os membros da esquerda revolucionária - no sentido militar, pois as torturas ainda são negadas. O filme coloca em pauta, exatamente, membros da sociedade brasileira rural e pobre que nem poderiam ser considerados revolucionários, embora assumissem posições políticas mais à esquerda e, por isso, constituíam-se como adversários do regime. Enfim, com esta sequência, o cineasta desmente o discurso oficial forjado pela ditadura.

A história do filme inicia-se com a criação da Liga de Galileia, contada pelo sobrevivente, João Virgínio da Silva e com imagens diversas da região em 1981. O homem explica as condições de vida e morte na região e os passos para que se criasse a primeira Liga. Ali viviam cento e cinquenta famílias de "foreiros" que trabalhavam e pagavam ao proprietário o "foro". A Liga foi criada com o fim de resolver problemas ligados à morte, na verdade, ao enterro dos moradores do engenho, pois eles precisavam recorrer à artimanha de pedir um caixão emprestado ao prefeito para enterrar seus mortos. Ao saber que a Liga não se preocupava somente com os mortos, o dono das terras resolveu expulsar todos os trabalhadores do "Engenho Galiléia".

Os trabalhadores então buscaram a justiça e encontram o advogado que viria a se tornar o grande defensor das Ligas, Francisco Julião Arruda de Paula. Membro do Partido Socialista Brasileiro desde 1947, Francisco Julião era um político considerado líder do movimento dos "trabalhadores do campo" como diz Virgílio. Algumas imagens registram conversas do personagem Julião nos anos 1960 (COUTINHO, 1984, 11' 29').

$\mathrm{Na}$ história de Virgílio vamos nos dando conta que a luta "política" pela desapropriação do engenho tinha sido árdua. Segundo diziam os deputados, ela representava "muitas Galiléias" e que a desapropriação poderia fazer "pegar fogo no Brasil, de ponta 
a ponta!" Nessa sequência o público vê um "documento", uma caderneta mostrada por um trabalhador de "Galiléia", na qual está "registrado" a afiliação de um dos membros deste à criação da Liga (COUTINHO, 1984, 13’ 08”).

Enquanto isso, Gullar explica que a desapropriação foi realizada "através de justa e prévia indenização em dinheiro, como determinava a Constituição” de 1946 - considerada por juristas uma Carta Liberal. Mas, até hoje (1981) os "galileus" não têm as escrituras das terras, sentencia o narrador. Noutros termos, tratava-se de uma luta política permanente - insiste, metaforicamente, a narrativa. Afinal, o estado indenizou o proprietário, mas os trabalhadores ainda não detinham o registro legal de suas terras.

Segundo Coutinho, depois da chegada à Galileia, em 1981, a equipe de filmagem improvisou uma exibição do material filmado nos anos 1960 para os moradores do engenho. A chegada da Kombi com visitantes, as máquinas de projeção, tudo é exibido para o público. Nesse momento, o cineasta realiza uma ruptura com as convenções do documentário até então vigentes: o realizador aparece no filme e se apresenta ao seu público, deixando de ser um narrador onisciente e velado. Assume seu lugar de enunciação e revela a "verdade" do filme: um discurso sobre a realidade, um "ponto de vista" sobre as experiências humanas no tempo.

A obra realiza, então, outra contribuição - de caráter mais cultural do que histórico: "desconstrói” as mesmas convenções que são mobilizadas cotidianamente pelas mídias, visando à manipulação do passado. O filme de Coutinho "ensina" o público, por meio desse artifício cinematográfico, a observar essas estratégias com a finalidade de não se ver tão refém de manipulações muito características das linguagens audiovisuais.

Os atores eram convidados especiais para a projeção: atitude que também quebra a "magia" cinematográfica, colocando frente a frente, ator e personagem. Coutinho filma o encontro dos sobreviventes da aventura de 1964 e a experiência da exibição das filmagens passadas para todos os convidados no presente. O filme formula um diálogo entre as imagens dos homens/atores no passado e no presente, oferecendo para os participantes das "comemorações", 
inclusive o público dos cinemas - nos anos 1980 e/ou atualmente, registros da passagem do tempo, um confronto entre as filmagens dos anos 1960 e dos anos 1980.

As imagens dos personagens do passado e do presente do filme servem para que o público opere, cognitivamente, o reconhecimento da passagem do tempo e testemunhem a historicidade dessa realidade (inclusive humana) que é explicitada visualmente, por meio da obra. Numa analogia às proposições de Rüsen para a narrativa histórica, o filme oferece, em relação ao "conteúdo" da narrativa, a oportunidade de que o público possa "aprender a olhar o passado [que, nesse caso, não é um artifício de linguagem] e resgatar sua qualidade temporal"' (RÜSEN, 2010, p. 59).

Alguns dos chamados dispositivos do cinema são colocados em questão pelas posições assumidas no filme na relação ator/passado personagem/presente. Os realizadores têm a participação explicitada na construção da narrativa e muitas das convenções cinematográficas estão sendo "reveladas" ao público de Galileia e das salas de cinema onde o filme é exibido. Mas, ao contrário do que se poderia esperar, o deslocamento da verossimilhança característica do cinema confere à obra mais confiança, apresentando o "registro audiovisual".

A exibição dos fragmentos do primeiro filme transforma-se em evento em Galileia e é o mote que permite a Coutinho traçar as trajetórias dos atores/personagens de seu antigo filme. Todos ainda vivendo uma situação de trabalhadores, o que levou o evento a ser realizado em um sábado. O cineasta coloca em close um dos atores do filme e explica:

Braz Francisco da Silva foi o único dos atores do filme que prosperou: em seu sítio de quatro hectares produz verduras que vende no CEASA [tipo de mercado atacadista de produtos agrícolas] do Recife. Seis de seus filhos estão em São Paulo e três moradores o ajudam no trabalho. Dando duro na lavoura desde os oito anos, Braz se confessa cansado e diz que quer vender o sítio (COUTINHO, 1984, 17' 37'-17' 59”). 
A seguir, o cineasta pergunta ao personagem se ele quer mesmo vender o sítio. Ele afirma que fugiu de Galileia em 1964, trocou de nome para evitar perseguições, se desiludiu com a política e não gosta de falar sobre isso. Não são sequências inócuas. Ao contrário, as imagens e os testemunhos apresentados pelo cineasta deixam a impressão de que o material que o público vê na tela é uma verdade incontestável. Isso se desdobra ao longo da narrativa.

Há uma série de diálogos com as sequências seguintes nas quais os testemunhos de vida são mais graves. Nelas, outros atores são apresentados de forma que os personagens voltem a figurar na tela e confirmem a situação de permanência das (péssimas) condições em que todos se encontravam no início dos anos 1960, de maneira que o "sucesso" relativo de Brás se evidencia como exceção. A noção de "reação responsiva" bakhtiniana é fundamental, isso porque o resultado não é atribuído a dispositivos de retórica cinematográfica, mas sim de conclusões que a diegese fílmica nos leva a reconhecer.

O filme corrobora, afinal, a história/História - negada e/ou silenciada - e cujos "testemunhos" não deixam dúvida: as condições de vida no campo, ao longo dos dezessete anos de ditadura, mantiveram-se as mesmas. No entanto, não há uma réstia de retórica na narrativa do Cabra. Se existe retórica, ela se apresenta, cinematograficamente: os personagens reais, desdentados, com rostos marcados pelo trabalho árduo, das marcas do sol e das condições de vida muito limitadas são elementos registrados pelas câmeras, bem como os testemunhos orais servem de "prova", atestam a realidade empírica incontornável. Novamente, a ausência de uma retórica política e/ou social funciona de maneira a conferir ao filme uma qualidade: trata-se de um registro que não se abre a contestações de quaisquer natureza.

Elizabeth Teixeira, viúva do líder camponês morto em 1962, logo foi reconhecida pelo público na exibição em Galileia (COUTINHO, 1984, 21' 27"-21' 46"). A sequência é registrada pelas câmeras de 1984 e formula um diálogo entre passado (em preto e branco) do qual o filme foi testemunha e presente (colorido) que este novo trabalho permite registrar. Uma experiência de reconhecimento pelas imagens. 
Ocorre o registro cinematográfico de uma experiência coletiva/ social que nos é dado a ver nas salas de projeção. Uma experiência que somente o cinema permite realizar. Formula-se um diálogo que, cinematograficamente, coloca frente a frente passado e presente, exibindo visualmente os traços humanos da passagem do tempo e da historicidade humana, convidando-nos todos a experimentar, a "presenciar", (quase) a participar do evento.

O cinema aqui é meta-cinema: faz o público ver e o "interpela" a participar deste encontro "histórico". Mobiliza nossa atenção e emoção como seres que reconhecem sua historicidade, sua humanidade histórica. Há, portanto, um apelo emocional que se opera pelo reconhecimento do tempo histórico que é partilhado por uma comunidade, que poderia ser considerada nacional. Afinal, a ditadura que surge, velada e metaforicamente, na vida desses personagens foi uma experiência partilhada por todos os brasileiros, inclusive o público das salas de cinema, ainda que não da mesma forma.

A presença cinematográfica de Elizabeth permite ao cineasta explicar que ela estava desaparecida desde 1964. Inicia-se então a saga da equipe em busca dessa personagem da vida real e sua história. A viúva do líder camponês vivia, sob nome falso de Marta Maria da Costa, numa cidadezinha onde nem mesmo sinal de televisão chegava, com um dos seus onze filhos.

$\mathrm{Na}$ primeira entrevista de Elizabeth, seu filho mais velho, Abraão, diz:

"reconheço a abertura política do presidente Figueiredo" "graças a ele, nós estamos aqui". A mãe completa: "graças a ele eu estou aqui hoje, com a presença de vocês" (COUTINHO, 1984, 24' 05"-24' 13"). “Eu não tinha mais esperança... de nunca mais encontrar, nem sequer com meus filhos"..."A perseguição era grande! Os caras tinham esperança de me exterminar." (COUTINHO, 1984, 25' 15”) "Antes eu era calada. Assombrada... Mas, graças a Deus, hoje estou aqui, contando a história. E o João Alfredo, e o Pedro fazendeiro?” [que foram assassinados] pergunta. (COUTINHO, 1984, 26' 20"'-31'00"). 
O testemunho da heroína da história é comovente e muito contundente; revela um aspecto da ditadura ao qual há pouca referência historiográfica: o medo. As pessoas, sob uma ditadura, estão em constante estado de alerta. A sensação de estar sob ameaça permanente é muito citada pelos membros da luta armada, mas pouco se fala dela entre a população em geral (FICO, 2004). As ameaças que o regime representa no cotidiano espreitam todos os membros da população e a todo o momento. Uma marca que, certamente, caracteriza o clima que perpassa todas as práticas individuais e/ou sociais, independente de seu caráter. Todos permanecem "assombrados”, como Elizath, pelos fantasmas da opressão e violência.

No testemunho, Elizabeth não fala, pois, somente de sua vida, mas da vida de todos os brasileiros que viveram sob a ditadura, exceto aqueles que não sabiam o que ocorria. Afinal, mesmo os que consideravam ter alguma garantia sob um regime de exceção, sabiam que a situação de uma ditadura é sempre incerta. A sequência interpela todos aqueles que viveram durante o período da ditadura, trazendo o medo do período para o presente, colocando-o na pauta dos debates sobre a ditadura, evidenciando esse traço que marcou a vida brasileira e que tendia a ser apagado das memórias e até da História.

Abraão afirma, um pouco exaltado que: "nenhum [sistema de governo] presta para o pobre! ", pedindo que Coutinho registre essa sua opinião. Observamos que o filho mais velho de um dos mais importantes líderes do movimento dos trabalhadores rurais da história do Brasil não tem uma visão clara dos processos aos quais foi submetido. $O$ aprendizado político que o convívio com o pai poderia lhe oferecer, permitindo que ele construísse uma reflexão mais elaborada da vida política, se perdeu. Não só para ele, mas para toda uma geração de brasileiros que cresceu e viveu por vinte e um anos sob uma ditadura.

O testemunho fala por si. O filme é, nesse aspecto, finalista: trata-se de um dado e o que se pode fazer é reconhecê-lo. No entanto, para que o reconhecimento ganhe efetivo caráter de denúncia é necessário que se esteja muito atento à narrativa e que se tenha refletido a respeito das perdas que ocorreram também, ou talvez, sobretudo, no campo de uma cultura política. 
Coutinho explica, em voz off que "a presença de Abraão havia influído no clima da primeira entrevista com Elizabeth".

Nas sequências seguintes Elizabeth (re)toma a palavra: a heroína reconquista sua "voz", fala de sua "história", abandona a vida clandestina, a qual ficou submetida ao longo da ditadura e oferece às câmeras (e ao púbico) seu testemunho da luta dos trabalhadores rurais brasileiros antes do golpe de 1964. As duas sequências nas quais observamos posições políticas tão díspares, não somente em termo ideológicos, mas, sobretudo, de reflexão sobre a realidade (histórica) põem em destaque alguns dos aspectos aos quais fizemos menção anteriormente.

Há um corte na montagem e o filme apresenta um companheiro de João Pedro no trabalho da cidade. Segundo seu testemunho, depois que João passou a participar do sindicato, o trabalho escasseou. Então ele resolveu voltar para a zona rural. Mas, quanto ao perigo das Ligas, ele havia dito ao companheiro que: "posso até morrer 'a bala', mas é melhor que morrer aqui, de fome" (COUTINHO, 1984, 33' 35”-33' 52”').

A ideia expressa por esse homem do povo e atribuída ao "herói" do filme é muito impactante. Há também um apelo estético difícil de alcançar em uma narrativa escrita e que o cinema é capaz de realizar por meio de uma sequência: o testemunho audiovisual, o personagem real e a lembrança narrada. Além disso, a sequência, em diálogo como algumas das anteriores torna explícitas e incontornáveis as condições em que viviam esses migrantes rurais, principalmente do nordeste - um artifício que, comparado a linguagem escrita, seria caracterizado como retórico.

A sentença de morte de Pedro Teixeira e de todos os demais migrantes nordestinos nessas mesmas condições estava, então, preestabelecida. Restava ao trabalhador escolher como ocorreria. O Cabra [estava, pois] marcado para morrer! 


\section{O Brasil em cena}

O trabalho pretendeu apreender alguns dos significados que o filme Cabra marcado para morrer configurou, ao ser exibido nas salas brasileiras de cinema. O exercício foi concebido como a recupe$\infty$ ração dos "diálogos" que se travaram entre obra cinematográfica - e a Cultura História sobre a ditadura civil-militar no Brasil dos anos N 1980. Ao objetivarmos os possíveis "diálogos" nascidos nas interações sociais que se constituíram entre os diversos discursos sobre a história que circulavam na cultura, povoavam as mentes de homens e mulheres que formavam os públicos desses cinemas, conferimos um caráter de fonte histórica e, por que não, de cine-historiografia ao filme de Coutinho.

Ao procurarmos apreender a obra como diálogo, tentando dar conta da experiência de se assistir ao filme naquela época, acreditamos que esclarecemos como alguns dos "significados" que a obra pretendeu oferecer ao público poderiam ter emergido no contexto sociocultural e histórico do ocaso da ditadura civil-militar brasileira. Ainda que tenhamos claro que conhecer a cultura que os brasileiros dos anos 1980 compartilhavam seria uma generalização arriscada, acreditamos que o trabalho oferece elementos para apreender uma "recepção social" do Cabra marcado para morrer.

Finalmente, o emprego do filme, não somente como testemunho de época, mas, sobretudo, como escrita audiovisual da história esclarece e aproxima-o de uma obra historiográfica, permitindo demonstrar a pertinência da metodologia empregada e as possibilidades "objetivas" que ela oferece para apreender significados de uma obra audiovisual em seus próprios termos, recorrendo à Cultura Histórica de época para esse fim. Sobretudo, contribui para refletirmos sobre a arte e a magia que aproximam as narrativas de cineasta e historiador. 


\section{CABRA MARCADO PARA MORRER: A FILM BETWEEN HISTORY AND MEMORY}

Abstract: This paper is a research about the movie Cabra marcado para morrer (1984), the Brazilian filmmaker Eduardo Coutinho. The paper explores some possibilities to grasp the impact of the work at the time it goes public. It is a historiographical research study, taking the Didactic of History (RÜSEN) as a theoretical paradigm and use theories of Vygotsky, Bakhtin and Williams in an articulated, of way to demonstrate some of the procedures employed by the filmmaker are similar to those employed by historians. Thus, we investigated the possibilities to apprehend the relationships that the film set with the historical culture of the 1980s and as narrative can be considered a work "between memory and history," approaching an audiovisual writing of history.

Keywords: Didactics of History. History and audiovisual narratives. Dictatorship.

\section{Notas}

${ }^{1}$ LE GOFF, 1997, p. 62.

${ }^{2}$ Não desconhecemos algumas das respostas a questão, a maioria afirmativa, especialmente aquelas oferecidas por Ferro (1992), Davis (1987) e Rosenstone (2010). Ver também sobre o tema Nóvoa et al., 2009.

3 A noção de "dialogismo" como fundamento da linguagem e elemento estruturante da cultura tem sido explorada em diversos campos de conhecimento, como linguística, literatura, antropologia, psicologia e comunicação.

${ }^{4}$ Conferir em Marxismo e literatura (1979; 1971, p. 27-49).

${ }^{5}$ A concepção é defendida como traço antropológico por autores como Vigotski (2010), Habermas (1992) e Geertz (1989).

${ }^{6}$ Wertsch (1993) observou que conceitos de Vygotsky podem ser "aproximados" aos de Bakhtin. Nesse sentido, pode-se o empregar obras de linguagem como análogas ao uso de ferramentas nos processos de trabalho, aproximando-as da noção de "signo" e/ou "discursos", conforme Vygotsky e de "discurso" conforme Bakhtin.

${ }^{7}$ Nessa perspectiva, pode-se concluir que, tanto Rüsen quanto Williams concebem processos e papeis sociais análogos, desempenhados pela História e pela Arte, respectivamente.

${ }^{8}$ Rüsen considera que essa é a característica que distingue as narrativas históricas das demais narrativas. (RUSEN, 2010).

${ }^{9}$ Autores como Stam (1992) e Williams (2003; 1971) têm defendido a pertinência do emprego das noções bakhtinianas, também historiadores, como Darton (1990) 
e Burke (2004). Aproximam-se da perspectiva "dialógica" na metodologia que imprimem em seus trabalhos Morettin (2003), Napolitano (2012), sobretudo, Schvarzman (2014).

${ }^{10}$ A década de 1980 tem sido definido como de "lutas pela memória". Sobre esse debate consultar Reis Filho (2004).

${ }^{11}$ Empregamos Skidmore (1988) como fonte historiográfica, um dos importantes discursos que compõe a Cultura História de época.

${ }^{12}$ Sobre o tema ver, entre outros, Napolitano (2001) e Ridenti (2005).

${ }^{13}$ Uma tomada clássica do filme de Glauber Rocha, Terra em transe (1967), na qual o poeta/intelectual tapa a boca de um personagem que representa "o povo" para, em seguida, acusá-lo de ser: "um despolitizado", "um analfabeto político" talvez expresse de forma exemplar uma das posições desse debate.

${ }^{14} \mathrm{O}$ preconceito pode ser um desdobramento da "tradição" brasileira relacionada ao trabalho e a escravidão.

${ }^{15}$ Ver Stam (1992).

${ }^{16}$ A ausência de uma historiografia sobre a ditadura transformou o livro de Skidmore (1988), De Castelo a Tancredo, em best-seller da década de 1980.

${ }^{17}$ Os termos voz, off ou over referem-se a presença diegética do narrador: quando ele conhecido, embora não esteja em cena, trata-se de voz off; mas quando somente há a voz do narrador é reconhecida pelo público é a vozover.

\section{Referências}

BAKHTIN, Mikhail (VOLOCHINOV). Marxismo e filosofia da linguagem. São Paulo: Hucitec, 1997.

. Gêneros do discurso. In: Estética da criação verbal. São Paulo:

Martins Fontes, 1992.

BURKE, Peter. Testemunha ocular: história e imagem. Bauru: EDUSC, 2004.

CERTEAU, Michel de. A invenção do cotidiano: 1. Artes de fazer. Petrópolis: Vozes, 1996.

DARTON, Robert. Cinema: Danton e o duplo sentido. In: - O Beijo de Lamourette: Mídia, cultura e revolução. São Paulo: Cia. Das Letras, 1990. p. 51-53.

DAVIS, Nathalie Z. O retorno de Martin Guerre. Rio de Janeiro: Paz e Terra, 1987. DREIFUSS, Réne A. 1964, a conquista do estado: ação política, poder e golpe de classe. Petrópolis: Vozes, 1981.

FERRO, Marc. Cinema e História. Rio de Janeiro: Paz e Terra, 2010. 
FICO, Carlos. Além do golpe: versões e controvérsias sobre 1964 e a ditadura militar. Rio de Janeiro: Record, 2004.

GAUTIER, Guy, O documentário: um outro cinema. Campinas, SP: Papirus, 2011. GINZBURG, Carlo. Sinais. In: . Mitos, Emblemas e Sinais. São Paulo: Cia das Letras, 1989. p. 143-179.

LE GOFF, Jacques. Uma vida para a história. São Paulo: Unesp, 1997.

MORETTIN, Eduardo V. O cinema como fonte histórica na obra de Marc Ferro. História: Questões \& Debates, Curitiba, n. 38, p. 11-42, 2003.

NAPOLITANO, Marcos. A arte engajada e seus públicos (1955/1968). Estudos Históricos, Rio de Janeiro, n. 28, 2001, p. 103-124.

- Nunca é cedo para se fazer história: o documentário Jango, de Silvio Tendler. In: MORETTIN et al. História e documentário. (Org.). FGV: Rio de Janeiro, 2012, p. 152-178.

NÓVOA, Jorge; FRESSATO, Soleni B.; FEIGELSON, Cristian (Org.). Cinematógrafo: um olhar sobre a história. Salvador; São Paulo: EDUFUBA; Editora UNESP, 2009.

REIS Fa., Daniel A. Ditadura e sociedade: as reconstruções da memória. In: REIS Fa., Daniel A.; RIDENTI, Marcelo; MOTTA, Rodrigo P. S. (Org.). O golpe e a ditadura militar: 40 anos depois (1964-2004). Bauru: Edusc, 2004, p. 29-52.

RIDENTI, Marcelo. Artistas e intelectuais no Brasil pós-1960. Tempo Social: revista de sociologia da USP, São Paulo, ano 1, v. 17, jun. 2005, p. 81-110.

. Em busca do povo brasileiro. Rio de Janeiro: Record, 2000.

ROSENSTONE, Robert A. A bistória nos filmes, os filmes na história. São Paulo: Paz e Terra, 2010.

RÜSEN, Jörn. Razão bistórica. Teoria da História I: fundamentos da ciência histórica. Brasília: Editora Universidade de Brasília, 2001.

. Reconstrução do passado. Teoria da História II: os princípios da pesquisa histórica. Brasília: Editora Universidade de Brasília, 2007a.

. História Viva. Teoria da História III: formas e funções do conhecimento histórico. Brasília: Editora Universidade de Brasília, 2007b.

SCHVARZMAN, Sheila. Construindo a história na televisão: Marc Ferro e os Cinejornais em Histoire Parallèle. Revista Tempo, Niterói, v. 20, 2014. [Epub]: 30 jan. 2015.

SKIDMORE, Thomas. Brasil: de Castelo a Tancredo, 1964 a 1985. Rio de Janeiro: Paz e Terra, 1988.

Anos 90, Porto Alegre, v. 24, n. 45, p. 267-292, jul. 2017 
Cabra marcado para morrer: um filme entre história e memória

STAM, Robert. Bakbtin: da teoria literária à cultura de massa. São Paulo: Ática, 1992.

STAM, Robert; SHOHAT, Ella. Critica da imagem eurocêntrica. São Paulo: Cosac Naify, 2006.

VIGOTSKI, Lev S. A construção do pensamento e da linguagem. São Paulo: Martins N Fontes, 2010.

VYGOTSKY, Lev S. A formação social da mente. São Paulo: Martins Fontes, 1994. WERTSCH, James V. Voces de la mente. Madrid: Visor Distribuciones S/A, 1993. _. Voices of Collective Remembering. Cambridge: Cambridge University Press, 2002.

WILLIAMS, Raymond. La larga revolución. Tradução Horacio Pons. Buenos Aires: Nueva Visión, 2003.

. Literatura e marxismo. Rio de Janeiro: Zahar Editores, 1979 [1971].

Recebido em: 08/05/2016

Aprovado em: 15/10/2016 